\title{
The Place of Change and Continuity Perception, Time and Chronology Perception Skills in the Curriculum of the Social Studies
}

\author{
Şenol Mail PALA 1 \\ Erzincan Binali Yıldırım University, Erzincan, TURKEY
}

${ }^{1}$ Assistant Professor at the Refahiye Bahar Ylldırım Health Services Vocational School, Child Development Program. senol.pala[at] erzincan.edu.trl ORCID: 0000-0002-0489-9557

\begin{abstract}
Perception of change and continuity and perception of time and chronology are among the skills expected to be acquired by students through the Social Studies course curriculum (SSCEC). These skills are included in the SSCEC, which was updated in both 2005 and 2018. It is aimed to attainment, develop and transfer these skills to students by making associations with many learning areas in SSCEC and with the achievements included in these learning areas. It is important to what degree these skills, which are among the basic skills of the social studies course, are included in the curriculum. For this reason, the aim of the study was to determine how much and at what level the ability to perceive change and continuity and to perceive time and chronology were given in SSCEC. The qualitative research model and document review method were used in the study. Due to the study of the relationship between change and continuity perception and time and chronology perception skills with SSCEC, SSCEC has been identified as the data source of the study. The data is analyzed by descriptive analysis technique. According to the results of the study, it was achieved that the ability to perceive change and continuity and to perceive time and chronology are included in SSCEC at all class levels and in all learning areas. In addition, it was determined that the ability to detect change and continuity in SSCEC includes the ability to detect continuity and change that occurs with the most time, and the ability to detect time and chronology includes indicators for interpreting data in the most time lane.
\end{abstract}

\section{Keywords}

Social Studies, Perception of Change And Continuity, Perception of Time And Chronology, Skill 
Due to rapid developments and changes in the world, individuals need various achievements in many areas and various skills to transfer these achievements to their lives (Gömleksiz \& Cüro, 2011). The issue of acquiring skills for individuals has generally been a task assigned to educational institutions and training programs, hence education (Hayırsever, 2010). In order to adapt to the changes and developments in our country, the acquisition of skills for individuals has been one of the important stages of these studies. In this context, in addition to providing high-level skills to individuals in the curricula updated in 2018, it is aimed that each course will provide its own skills to individuals at a basic level (Ministry of National Education [MoNE], 2018).

Although skill acquisition is one of the aims of the curriculum of almost every course, it has a very important place in the Social Studies course (Hayırsever, 2010). Social Studies have always been one of the most responsible courses for meeting the needs of society (Gömleksiz \& Cüro, 2011). One of the main aims of Social Studies teaching is to enable individuals to acquire and develop various skills (Akbaba, Aksoy \& Kilcan, 2019). The course has attainmented some skills and active citizens are sensitive to social problems and the purpose of training from individual's attainment skills through individual and social problems being solved in terms of the concept of skills is quite important in Social Studies (Avcl \& Faiz, 2018).

The skills involved in SSCEC have been associated with many achievements. In order to attainment SSCEC attainments for students, the basic principles of Social Studies teaching such as time, continuity and change should be taken into account with the connection of the past, present and future (MoNE, 2018). Therefore, the basic concepts to be taught in this course include time, chronology, change and continuity (Demircioğlu, 2006; İncegül, 2010). These concepts have also been reflected in skills teaching. Although many skills are included in SSCEC, the ability to perceive change and continuity (CCPS), which includes these concepts, and the ability to perceive time and chronology (TCPS), are included in the skills included in the program.

The main basis of CCPS is that our world is in a constant state of change. The perception of this change by students in the context of the past, present and future is very important for them to make sense of life (Demircioğlu, 2006; Kabapınar \& Sağlamgöncü, 2018). A better understanding of how social events, people, places and objects have changed and developed from the past to the present is also related to CCPS (Demircioğlu, 2006). This skill has an important contribution to the formation of time consciousness in students and the realization of Social Studies course achievements (Özen \& Sağlam, 2010). It is very important for students to understand that change is continuity and to perceive that everything is in a change. From this point of view, it is necessary for students to internalize the past, present and future relationship in the Social Studies course in order to recognize society, culture and themselves (Çelik, Karadeniz \& Cabul, 2018).

Many studies have been conducted on CCPS. Çelik, Karadeniz \& Cabul (2018), based on the example of hospitality in social studies classes, presented students' assessments of CCPS. Tangülü, Tosun \& Topkaya (2015) and Özen and Sağlam (2010) investigated CCPS levels in Social Studies class of secondary school seventh grade students. Kabapınar \& Sağlamgöncü (2018) investigated the effectiveness of 
figure reading in CCPS in Social Studies courses. Secim (2019) examined the teacher's views on the place, importance, internalization and level of implementation of CCPS in the curriculum for the geography course.

Basic concepts related to time and chronology are important in terms of formation students' consciousness of the past tense. Explaining events that happened in the past without specifying the time causes the connections between these events to become disconnected. This also makes it a necessity to know the concepts related to time and chronology accurately and fully (Çelikkaya, 2019). But the acquisition and development of skills related to time and chronology by children covers a long period of time (Altun \& Kaymakcl, 2016). Although TCPS is one of the long-lasting skills acquired by students, this skill was among the common skills of the 2005 and 2018 SSCEC.

Looking at current studies on TCPS; Çelikkaya (2019) investigated the level of understanding of some basic concepts related to TCPS, which are necessary for secondary school seventh and eighth graders to perceive history topics in Social Studies classes. Kekeç (2018) demonstrated the effectiveness of the modeling process in attainment TCPS in Social Studies class to secondary school seventh grade students. Işık (2014) compared spatial cognition and chronology knowledge of secondary school sixth grade and high school ninth grade students. Şimsek (2007) conducted a study aimed at improving the chronological perceptions of secondary school fifth graders. Demircioğlu (2005) examined the level of understanding of eighth-graders' concepts related to time and chronology. Sağlam, Tınmaz \& Hayal (2015) examined the views of classroom teachers on the activities they benefit from in teaching TCPS. Safran \& Şimşek (2006) conducted a study on the development of the concept of historical time in primary school students. Altun \& Kaymakcı (2016) conducted a study on the theoretical knowledge of the place of time and chronology and time strips in the teaching of history. Akbaba, Keçe \& Erdem (2012) examined the effect of multimedia use in the seventh-grade social studies course learningteaching process on students ' attitudes towards TCPS and CCPS.

When looking at studies on CCPS and TCPS, it is usually seen that studies are conducted on the level of student's attainment these skills. But in the studies conducted, it seems that no studies have been conducted to link these skills and the attainment contained in the SSCEC. It is important to what degree these skills, which are among the basic skills of the Social Studies course, are included in the curriculum. For this reason, the study can be separated from other studies in terms of examining the degree to which these skills are included in the SSCEC. In this direction, the study aimed to determine how much and at what level CCPS and TCPS were given in SSCEC. Below are the sub-problems of the study in this direction;

1. How is the distribution of CCPS in classes and learning areas in SSCEC?

2. What are the attainments associated with CCPS in SSCEC and what indicators of CCPS are included in the attainment?

3. How is the distribution of TCPS in SSCEC in classrooms and learning areas?

4. What is the attainment associated with TCPS in SSCEC and what indicators of TCPS are included in the attainment? 


\section{Methodology}

\section{Research Design}

In the study, the state analysis design, which is one of the qualitative research models, was used. In case analysis, the aim is to examine a particular situation in detail and to reveal detailed results about that situation (Kıncal, 2017, p. 109). In this context, a situation study was conducted on the relationship of CCPS and TCPS with SSCEC. In order to ensure the suitability of the research for its purpose, the document review method was used in the case study. Document review: data on the subject of the study is obtained from various documents. In the document review, data is obtained by analyzing written materials containing information on the subject being investigated (Yıldırım \& Şimşek, 2006, p. 187; Gürbüz \& Şahin, 2018, p. 430). In this technique, also called documentary surveying, data is collected from various documents (Karasar, 2017, p. 229; Kıncal, 2017, p. 173). In educational Studies, data is obtained from various documents, especially written curricula, course drafts, timelines and communiques (Robson, 2017, p. 401). The document, which has the necessary content to achieve the purpose of the study, was also the focus of the topic of the study.

In the study, the criteria included in the purposeful sample types were used. A criterion sample can be expressed as a selection of all situations that provide certain criteria (Patton, 2014, p. 213). In the study, it was determined that CCPS and TCPS indicators should be included in the attainment contained in SSCEC as criteria. CCPS and TCPS indicators are taken directly from MoNE (2005).

\section{Data Collection}

In order to collect data, two separate checklists were created for CCPS and TCPS in accordance with the opinions of experts in the fields of literature review, Social Studies education and assessment, measurement and evaluation contained in the SSCEC. The checklists include the CCPS and TCPS indicators included in the 2005 SSCEC (MoNE, 2005).

Indicators of CCPS are finding similarities and differences, perceiving continuity and change that occur over time, distinguishing historical facts and interpretations, recognizing past problems and their causes, finding alternative solutions to solving a historical problem (MoNE, 2005).

Indicators of TCPS are, respectively, obtaining calendar information, distinguishing times (past, present and future tense), correct use of time expressions, chronological sorting, interpreting data in the time strip, creating a time strip (MoNE, 2005).

In addition, a list of 131 achievements and descriptions of these achievements has been prepared in the SSCEC. Two groups were formed as two different skills were examined in the study while data was collected. That attainments match skills indicators were placed in these two groups using checklists.

In order to ensure the reliability of the process, the internal consistency of the results of these two grouping processes was compared after the grouping process was performed twice with a break of 15 days by the researcher and a social studies 
education expert. At least $80 \%$ consensus must be achieved between groupings to ensure internal consistency (Miles \& Huberman, 1994; Patton, 2002). In the study, a consensus of $88.9 \%$ for CCPS and $87.5 \%$ for TCPS was achieved between the first and second grouping processes. During these two grouping processes, opinions were taken from three different experts in 2 attainment for CCPS and 2 wins for TCPS, which were ambivalent about placing attainment in groups. According to the opinions, it was decided to place these attainments in the designated group. In this way, it was determined which attainments CCPS and TCPS were relationship with.

\section{Data Analysis}

Descriptive analysis technique was used to analyze the collected data. The data collected in this technique is interpreted according to pre-determined themes. After a clear and systematic description of the results, descriptions are explained, interpreted, associated and conclusions are reached (Yıldırım \& Şimşek, 2006, p. 225-226). The theme of the study was CCPS and TCPS, and its codes were indicators of these skills. In the study, the data were edited and interpreted in accordance with the theme of the problem situation. If some attainments are related to more than one indicator of CCPS and TCPS when analyzing the data, the basic indicator included in the skill was preferred in accordance with expert opinions.

In the study, the attainments associated with CCPS and TCPS in SSCEC were table and presented. In the tables, the indicators that these skills are associated with achievements are also given. In addition, in order to make the association better, where necessary, the explanations of the attainments contained in the program were also used. The relationship between CCPS and TCPS with the attainments has been interpreted in this context and various results have been put forward.

\section{Findings}

\section{Findings on the Distribution of CCPS to Classes and Learning Areas in SSCEC}

Table 1 shown the distribution of CCPS to classes and learning areas according to SSCEC.

Table 1

Distribution of CCPS to Classrooms and Learning Areas in SSCEC

\begin{tabular}{|c|c|c|c|c|c|c|c|}
\hline \multirow[b]{2}{*}{ Grade } & \multicolumn{7}{|c|}{ Learning Area } \\
\hline & 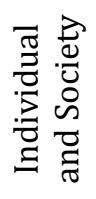 & 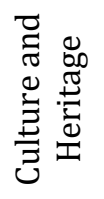 & 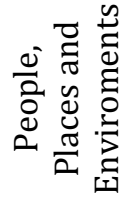 & 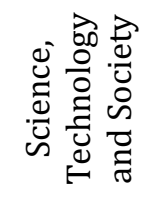 & 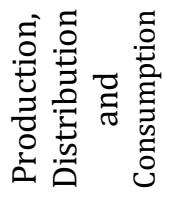 & 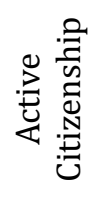 & 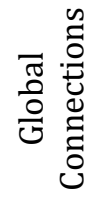 \\
\hline 4. Grade & & $\mathrm{X}$ & $\mathrm{X}$ & $\mathrm{X}$ & & & \\
\hline 5. Grade & & $\mathrm{X}$ & & & & $X$ & \\
\hline 6. Grade & $\mathrm{X}$ & $\mathrm{X}$ & & & & $\mathrm{X}$ & $\mathrm{X}$ \\
\hline 7. Grade & $X$ & $X$ & $X$ & $X$ & $X$ & & \\
\hline
\end{tabular}


Pala, S. M. (2021). The place of change and continuity perception, time and chronology perception skills in...

CCPS to SSCEC in Table 1 according to the "individual and society" in the field of learning in sixth and seventh grade, "culture and heritage" in the field of learning, fourth, fifth, sixth, and seventh grade, "people, places and environments" and "science, technology and society" in the areas of learning in fourth and seventh grade, "production, distribution and consumption" learning in the area of seventh grade, and "active citizenship" in the area of fifth and sixth grade learning, and "Global Connections" in the area of sixth grade learning attainments is given. According to Table 1, CCPS is included in all class levels and learning areas in SSCEC. This indicates that CCPS is a very important skill for the program.

\section{Attainments Associated with CCPS in SSCEC and Findings on Indicators of CCPS in Attainments}

Table 2

4. Grade Learning Areas, Achievements and Indicators Associated with CCPS in Class SSCEC

\begin{tabular}{|c|c|c|}
\hline Learning Area & Attainment & Indicator of Skill \\
\hline $\begin{array}{l}\text { Culture and } \\
\text { Heritage }\end{array}$ & $\begin{array}{l}\text { It compares traditional children's games } \\
\text { with today's games in terms of change } \\
\text { and continuity. }\end{array}$ & \multirow{3}{*}{$\begin{array}{l}\text { Detecting continuity } \\
\text { and change that occurs } \\
\text { over time }\end{array}$} \\
\hline $\begin{array}{l}\text { People, Places and } \\
\text { Enviroments }\end{array}$ & $\begin{array}{l}\text { By observing the weather events } \\
\text { occurring around it, transfers his findings } \\
\text { to illustrated graphs. }\end{array}$ & \\
\hline \multirow{3}{*}{$\begin{array}{l}\text { Science, } \\
\text { Technology and } \\
\text { Society }\end{array}$} & $\begin{array}{l}\text { It explores the inventors of the } \\
\text { technological products it uses and the } \\
\text { development of these products over time. } \\
\text { It explores the inventors of the } \\
\text { technological products it uses and the } \\
\text { development of these products over time. }\end{array}$ & \\
\hline & $\begin{array}{l}\text { It classifies the technological products } \\
\text { around it according to their area of use. }\end{array}$ & \multirow{2}{*}{$\begin{array}{l}\text { Finding similarities and } \\
\text { differences }\end{array}$} \\
\hline & $\begin{array}{l}\text { Compares past and present uses of } \\
\text { technological products. }\end{array}$ & \\
\hline
\end{tabular}

Looking at Table 2, in the fourth grade SSCEC, CCPS is associated with four achievements in the learning area "culture and heritage", one in the learning area "people, places and environments", and one in the field of learning "Science, technology and society". In the fourth grade SSCEC, the most attainments that can be associated with CCPS are included in the learning area "science, technology and society". In achievements, indicators of this ability to detect continuity and change over time, as well as finding similarities and differences were discussed.

Table 3

5. Grade Learning Areas, Achievements and Indicators Associated with CCPS in Class SSCEC

\begin{tabular}{lll}
\hline \multicolumn{1}{c}{$\begin{array}{c}\text { Learning } \\
\text { Area }\end{array}$} & \multicolumn{1}{c}{ Attainment } & Indicator of Skill \\
\hline & $\begin{array}{l}\text { By comparing the cultural characteristics of } \\
\text { various places of our country and the cultural } \\
\text { Characteristics of the environment in which it lives, } \\
\text { Heritage }\end{array}$ & $\begin{array}{l}\text { Finding similarities } \\
\text { it determines the similar and different elements } \\
\text { between them. }\end{array}$ \\
\hline
\end{tabular}




\begin{tabular}{|c|c|c|}
\hline & $\begin{array}{l}\text { Assesses the historical development of cultural } \\
\text { elements in daily life. }\end{array}$ & $\begin{array}{l}\text { Detecting } \\
\text { continuity and }\end{array}$ \\
\hline $\begin{array}{l}\text { Active } \\
\text { Citizenship }\end{array}$ & $\begin{array}{l}\text { It values our flag and National Anthem from our } \\
\text { symbols of national sovereignty and independence. }\end{array}$ & $\begin{array}{l}\text { change that occurs } \\
\text { over time }\end{array}$ \\
\hline
\end{tabular}

According to Table 3, in the fifth grade SSCEC, CCPS is associated with two attainments in the learning area "culture and heritage" and one in the learning area "active citizenship". In this acquisition, it was determined that the ability to perceive the continuity and change that occurs over time and the indicators of finding similarities and differences come to the fore.

Table 4

6. Grade Learning Areas, Achievements and Indicators Associated with CCPS in SSCEC

\begin{tabular}{|c|c|c|}
\hline Learning Area & Attainment & Indicator of Skill \\
\hline $\begin{array}{l}\text { Individual and } \\
\text { society }\end{array}$ & Examines the change of social roles over time. & \multirow{5}{*}{$\begin{array}{l}\text { Detecting } \\
\text { continuity and } \\
\text { change that occurs } \\
\text { over time }\end{array}$} \\
\hline \multirow[b]{2}{*}{$\begin{array}{l}\text { Culture and } \\
\text { Heritage }\end{array}$} & $\begin{array}{l}\text { He/She interprets the emergence of Islam and } \\
\text { the changes it brings with it. }\end{array}$ & \\
\hline & $\begin{array}{l}\text { He/She notices changes occurring in the } \\
\text { political, social and cultural areas with the } \\
\text { acceptance of Islam by the Turks. }\end{array}$ & \\
\hline $\begin{array}{l}\text { Active } \\
\text { Citizenship }\end{array}$ & $\begin{array}{l}\text { Based on Turkish history and current examples, } \\
\text { it realizes the value given to women in social life. }\end{array}$ & \\
\hline $\begin{array}{l}\text { Global } \\
\text { Connections }\end{array}$ & $\begin{array}{l}\text { He/She questions the effects of popular culture } \\
\text { on our culture. }\end{array}$ & \\
\hline
\end{tabular}

In sixth grade SSCEC, the achievements and learning areas associated with CCPS are included in table 4 . according to Table 4, it was determined that one acquisition in the learning area "individual and society", two in the learning area "culture and heritage", one in the learning area "effective citizenship" and one in the learning area "global connections" is related to this skill. In the achievements in Table 4, it is seen that this skill includes an indicator of the perception of continuity and change that occurs over time.

Table 5

Learning Areas, Achievements and Indicators Associated with CCPS In Seventh Grade SSCEC

\begin{tabular}{lll}
\hline Learning Area & \multicolumn{1}{c}{ Attainment } & Indicator of Skill \\
\hline $\begin{array}{l}\text { Individual and } \\
\text { society }\end{array}$ & $\begin{array}{l}\text { Discusses the role of media in social change } \\
\text { and interaction. }\end{array}$ & $\begin{array}{l}\text { Detecting } \\
\text { continuity and } \\
\text { change that occurs } \\
\text { over time }\end{array}$ \\
\hline & $\begin{array}{l}\text { He/She understands the processes that } \\
\text { forced the Ottoman state to change in } \\
\text { connection with the developments in } \\
\text { Europe. }\end{array}$ & $\begin{array}{l}\text { Recognize past } \\
\text { problems and their } \\
\text { causes }\end{array}$ \\
\cline { 2 - 3 } $\begin{array}{l}\text { Culture and } \\
\text { Heritage }\end{array}$ & $\begin{array}{l}\text { It draws conclusions about social and } \\
\text { economic change based on institutions that } \\
\text { emerged as a result of reform movements in } \\
\text { the Ottoman State. }\end{array}$ & $\begin{array}{l}\text { Detecting } \\
\text { continuity and } \\
\text { change that occurs } \\
\text { over time }\end{array}$ \\
\hline People, Places and & $\begin{array}{l}\text { It makes inferences about factors affecting } \\
\text { settlement from the past to the present } \\
\text { Enviroments }\end{array}$ & \multicolumn{2}{l}{} & \\
\hline
\end{tabular}


Pala, S. M. (2021). The place of change and continuity perception, time and chronology perception skills in...

\begin{tabular}{|c|c|}
\hline & $\begin{array}{l}\text { Discuss the causes and consequences of } \\
\text { migration through sample reviews. }\end{array}$ \\
\hline $\begin{array}{l}\text { Science, } \\
\text { Technology and } \\
\text { Society }\end{array}$ & $\begin{array}{l}\text { It examines change and continuity in the } \\
\text { protection, dissemination and transmission } \\
\text { of information. }\end{array}$ \\
\hline $\begin{array}{l}\text { Production, } \\
\text { Distribution and } \\
\text { Consumption }\end{array}$ & $\begin{array}{l}\text { Explain the importance of soil in production } \\
\text { and management with examples from the } \\
\text { past and present. } \\
\text { Assesses the effects of developments in } \\
\text { production technology on social and } \\
\text { economic life. } \\
\text { It recognizes institutions that have played a } \\
\text { role in acquiring a profession and obtaining } \\
\text { professional ethics in Turks throughout } \\
\text { history. }\end{array}$ \\
\hline
\end{tabular}

According to Table 5, in seventh grade SSCEC, CCPS of "individual and society" learning in the area of "culture and heritage" in the area of learning two, "people, places, and two learning environments in the area of "science, technology and society" learning in the area of "production, distribution and consumption" in the area of learning, it is observed that is associated with attainment of ten for a total of five. In SSCEC, the class with the highest number of attainments associated with CCPS at all grade levels was the seventh grade. Indicators of this ability to detect continuity and change that occur over time in achievements, as well as recognize past problems and causes were included.

\section{Findings on the Distribution of TCPS in Classes and Learning Areas in SSCEC}

Table 6

Distribution of TCPS in SSCEC to Classrooms and Learning Areas

\begin{tabular}{|c|c|c|c|c|c|c|c|}
\hline \multirow[b]{2}{*}{ Grade } & \multicolumn{7}{|c|}{ Learning Area } \\
\hline & 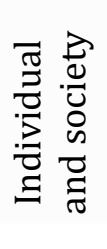 & 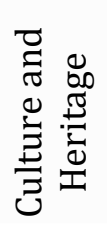 & 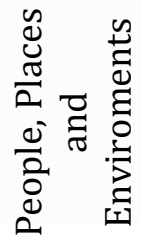 & 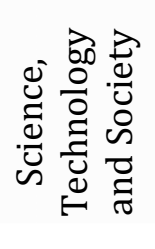 & 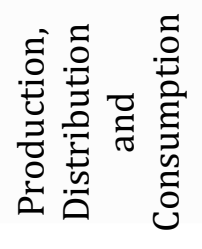 & 0. & 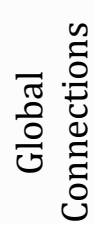 \\
\hline 4. Grade & $\mathrm{X}$ & $\mathrm{X}$ & $\mathrm{X}$ & & & $\mathrm{X}$ & \\
\hline 5. Grade & & $\mathrm{X}$ & & & & & \\
\hline 6. Grade & $\mathrm{X}$ & $\mathrm{X}$ & & & & $\mathrm{X}$ & $\mathrm{X}$ \\
\hline 7. Grade & & $\mathrm{X}$ & $\mathrm{X}$ & $\mathrm{X}$ & $\mathrm{X}$ & & \\
\hline
\end{tabular}

In SSCEC, the distribution of TCPS by classes and learning areas is shown in Table 6. This skill; "individual and society" learning in the field of fourth-and sixth-graders, "culture and heritage" of all the classes in the field of learning, "people, places, and learning environments in the area of fourth and seventh grade, "science, technology and society" and "production, distribution and consumption" learning for seventh grade in the areas of "active citizenship" learning in the area of fourth-and sixthgraders and "Global Connections" in the area of learning achievements is given in the sixth class. In Table 6, it was determined that CCPS is included in the 
achievements of all class levels and learning areas. This indicates that TCPS is a very important skill for the program.

\section{Findings for the Attainments Associated with TCPS in SSCEC and the Indicators of TCPS in the Attainments}

Table 7

4. Learning Areas, Achievements and Indicators Associated with TCPS In Class SSCEC

\begin{tabular}{lll}
\hline \multicolumn{1}{c}{ Learning Area } & \multicolumn{1}{c}{ Attainment } & \multicolumn{1}{c}{ Indicator of Skill } \\
\hline $\begin{array}{l}\text { Individual and } \\
\text { society }\end{array}$ & $\begin{array}{l}\text { It puts the main events related to life in } \\
\text { chronological order. }\end{array}$ & $\begin{array}{l}\text { Making } \\
\text { chronological order }\end{array}$ \\
\hline $\begin{array}{l}\text { Culture and } \\
\text { Heritage }\end{array}$ & $\begin{array}{l}\text { It makes use of oral, written, visual sources } \\
\text { and objects to study family history. }\end{array}$ & \begin{tabular}{l} 
Creating a timeline \\
\cline { 2 - 3 }
\end{tabular} \\
$\begin{array}{l}\text { It compares traditional children's games } \\
\text { with today's games in terms of change and } \\
\text { continuity. }\end{array}$ & Distinguishing times \\
\hline $\begin{array}{l}\text { People, Places and } \\
\text { Enviroments }\end{array}$ & $\begin{array}{l}\text { By observing the weather events } \\
\text { occurring around it, transfers his findings } \\
\text { to illustrated graphs. }\end{array}$ & Creating a timeline \\
\hline Active Citizenship & $\begin{array}{l}\text { Describes the relationship between the } \\
\text { independence of his/her country and } \\
\text { individual freedom. }\end{array}$ & $\begin{array}{l}\text { Interpreting data in } \\
\text { the time strip }\end{array}$ \\
\hline
\end{tabular}

Looking at Table 7, it is seen that an acquisition in the field of "individual and society" learning is associated with TCPS. In this acquisition, emphasis was placed on making chronological order. In the area of "culture and heritage" learning, it has been determined that two achievements are associated with this skill. In these achievements, emphasis was placed on creating a time strip and distinguishing times. It seems that an acquisition in the "people, places and environments "learning area is associated with this skill. In this acquisition, the time strip creation indicator is included. In the area of" effective citizenship " learning, TCPS has been associated with an acquisition. In this acquisition, the data interpretation indicator in the time strip is included.

Table 8

Learning Areas, Achievements and Indicators Associated with TCPS In Fifth Grade SSCEC

\begin{tabular}{|c|c|c|}
\hline $\begin{array}{l}\text { Learning } \\
\text { Area }\end{array}$ & Attainment & Indicator of Skill \\
\hline \multirow{3}{*}{$\begin{array}{l}\text { Culture and } \\
\text { Heritage }\end{array}$} & $\begin{array}{l}\text { Based on its concrete remains, it recognizes the } \\
\text { important contributions of Anatolian and } \\
\text { Mesopotamian civilizations to human history. }\end{array}$ & \multirow{2}{*}{$\begin{array}{l}\text { Interpreting data in } \\
\text { the time strip }\end{array}$} \\
\hline & $\begin{array}{l}\text { Evulate the historical development of cultural } \\
\text { elements in daily life. }\end{array}$ & \\
\hline & $\begin{array}{l}\text { It introduces natural assets and historical sites, } \\
\text { objects and artifacts around it. }\end{array}$ & $\begin{array}{l}\text { Distinguishing } \\
\text { times }\end{array}$ \\
\hline
\end{tabular}

According to Table 8, the three achievements in the area of "culture and heritage" learning in the fifth grade SSCEC are associated with TCPS. These attainments were found to be associated with indicators of this ability to interpret data in the time strip and distinguish times. 
Pala, S. M. (2021). The place of change and continuity perception, time and chronology perception skills in...

Table 9

Learning areas, achievements and indicators associated with TCPS in sixth grade SSCEC

\begin{tabular}{|c|c|c|}
\hline Learning Area & Attainment & Indicator of Skill \\
\hline $\begin{array}{l}\text { Individual and } \\
\text { society }\end{array}$ & Examines the change of social roles over time. & $\begin{array}{l}\text { Interpreting data in } \\
\text { the time strip }\end{array}$ \\
\hline \multirow{5}{*}{$\begin{array}{l}\text { Culture and } \\
\text { Heritage }\end{array}$} & $\begin{array}{l}\text { It draws conclusions about the geographical, } \\
\text { political, economic and cultural characteristics of } \\
\text { the first Turkish States established in Central } \\
\text { Asia. }\end{array}$ & \multirow{2}{*}{$\begin{array}{l}\text { Distinguishing } \\
\text { times }\end{array}$} \\
\hline & $\begin{array}{l}\text { Explain the role of historical trade routes in inter- } \\
\text { communal political, cultural and economic } \\
\text { relations. }\end{array}$ & \\
\hline & $\begin{array}{l}\text { It interprets the emergence of Islam and the } \\
\text { changes it brings with it. }\end{array}$ & \multirow{5}{*}{$\begin{array}{l}\text { Interpreting data in } \\
\text { the time strip }\end{array}$} \\
\hline & $\begin{array}{l}\text { It notices changes occurring in the political, social } \\
\text { and cultural areas with the acceptance of Islam by } \\
\text { the Turks. }\end{array}$ & \\
\hline & $\begin{array}{l}\text { The Turks of Anatolia, the process of obtaining } \\
\text { the country XI. and XIII. analyzes in the context of } \\
\text { centuries. }\end{array}$ & \\
\hline $\begin{array}{l}\text { Active } \\
\text { Citizenship }\end{array}$ & $\begin{array}{l}\text { Based on Turkish history and current examples, it } \\
\text { realizes the value given to women in social life. }\end{array}$ & \\
\hline $\begin{array}{l}\text { Global } \\
\text { Connections }\end{array}$ & $\begin{array}{l}\text { He/She questions the effects of popular culture } \\
\text { on our culture. }\end{array}$ & \\
\hline
\end{tabular}

In table 9, it was observed that TCPS was associated with one acquisition in the field of "individual and society" learning, five in the area of "culture and heritage" learning, one in the area of "active citizenship" learning, and one in the area of "global connections" learning in the sixth grade SSCEC. It seems that this skill addresses the indicators of distinguishing times and interpreting data in the time strip.

Table 10

Learning Areas, Achievements and Indicators Associated with TCPS In Seventh Grade SSCEC

\begin{tabular}{|c|c|c|}
\hline Learning Area & Attainment & Indicator of Skill \\
\hline $\begin{array}{l}\text { Culture and } \\
\text { Heritage }\end{array}$ & $\begin{array}{l}\text { It understands the processes that forced the } \\
\text { Ottoman state to change in connection with } \\
\text { the developments in Europe. }\end{array}$ & \multirow{3}{*}{$\begin{array}{l}\text { Interpreting data } \\
\text { in the time strip }\end{array}$} \\
\hline \multirow{2}{*}{$\begin{array}{l}\text { People, Places and } \\
\text { Enviroments }\end{array}$} & $\begin{array}{l}\text { It makes inferences about factors affecting } \\
\text { settlement from the past to the present } \\
\text { through sample investigations. }\end{array}$ & \\
\hline & $\begin{array}{l}\text { Discuss the causes and consequences of } \\
\text { migration through sample reviews. }\end{array}$ & \\
\hline \multirow{3}{*}{$\begin{array}{l}\text { Science, Technology } \\
\text { and Society }\end{array}$} & $\begin{array}{l}\text { Discusses the contribution of scholars who } \\
\text { grew up in Turkish-Islamic civilization to } \\
\text { the process of scientific development. }\end{array}$ & $\begin{array}{l}\text { Distinguishing } \\
\text { times }\end{array}$ \\
\hline & $\begin{array}{l}\text { It examines change and continuity in the } \\
\text { protection, dissemination and transmission } \\
\text { of information. }\end{array}$ & \multirow{2}{*}{$\begin{array}{l}\text { Interpreting data } \\
\text { in the time Strip }\end{array}$} \\
\hline & $\begin{array}{l}\text { 15. and } 20 \text {. Centuries analyzes the effect of } \\
\text { developments in Europe between on the }\end{array}$ & \\
\hline
\end{tabular}




\begin{tabular}{|c|c|c|}
\hline & $\begin{array}{l}\text { formation of modern scientific } \\
\text { accumulation. }\end{array}$ & \\
\hline \multirow{4}{*}{$\begin{array}{l}\text { Production, } \\
\text { Distribution and } \\
\text { Consumption }\end{array}$} & $\begin{array}{l}\text { Explain the importance of soil in production } \\
\text { and management with examples from the } \\
\text { past and present. }\end{array}$ & \multirow{2}{*}{$\begin{array}{l}\text { Distinguishing } \\
\text { times }\end{array}$} \\
\hline & $\begin{array}{l}\text { It plans for its professional preferences, } \\
\text { taking into account new professions that } \\
\text { arise due to developments in the world. }\end{array}$ & \\
\hline & $\begin{array}{l}\text { It recognizes institutions that have played a } \\
\text { role in acquiring a profession and obtaining } \\
\text { professional ethics in Turks throughout } \\
\text { history. }\end{array}$ & Creating a timeline \\
\hline & $\begin{array}{l}\text { Analyzes the changes caused by digital } \\
\text { technologies in the production, distribution } \\
\text { and consumption network. }\end{array}$ & $\begin{array}{l}\text { Interpreting data } \\
\text { in the time Strip }\end{array}$ \\
\hline
\end{tabular}

Ten attainments are associated with TCPS when looking at Table 10. It was determined that one of these attainments was related to "culture and heritage", two to "people, places and environments", three to "science, technology and society" and four to "production distribution and consumption" learning areas. In the achievements, it was achieved that TCPS included indicators for distinguishing times, interpreting data in the time strip, and creating a time strip. Compared to other tables, it seems that the number of attainments associated with TCPS is at most in the seventh class SSCEC.

\section{Result and Discussion}

It has been concluded that CCPS is included in SSCEC at all class levels and learning areas. In this direction, Şimşek \& Safran (2006) stated that primary school students were successful in attainment their perception of change and continuity. It has been achieved that this skill is more intensively involved in the achievements of the learning areas "culture and heritage", "science, technology and society", "production, distribution and consumption". It can be said that CCPS is suitable for the scope of all learning areas in terms of attainment and developing the student. But a balanced distribution of the 27 skills contained in the SSCEC in learning areas can lead to less participation in some learning areas. Looking at the relationship of CCPS with learning areas, it was found that the most associated learning area is "culture and heritage". Similarly, Akbaba, Keçe \& Erdem (2012) stated that CCPS should be acquired in this area of learning. The intensive content of the history and culture of this learning area may have led to a more intensive relationship with CCPS. Some studies have also included statements that CCPS is related to historical issues (Çelik, Karadeniz \& Cabul, 2018; Özen \& Sağlam, 2010). In contrast, in the geography course curriculum (2018), CCPS has been included in geographical skills. Similarly, Çiftçi \& Akça (2019) also demonstrated CCPS in geographical skills. Because CCPS is a process-expressing skill, it is normal to use this skill in that content if any process is involved, no matter what content it is. In addition, it was concluded that the program included the perception of continuity and change that occurs with the most time from CCPS indicators. 
In the fourth grade SSCEC, CCPS was more intensely associated with the achievements of "science, technology and society" learning areas, as well as with the association of "culture and heritage" with the achievements of "people, places and environments" learning areas. This can be explained by the fact that the achievements of this learning area include the change and development of technological products from the past to the present. In contrast, in the fourth grade SSCEC, CCPS "culture and heritage" has been shown as a skill that is expected to be acquired by students in the field of learning (MoNE, 2018). In the achievements, it was reached that this skill was considered to detect continuity and change that occurs over time, as well as indicators of finding similarities and differences.

In the fifth grade SSCEC, it was achieved that CCPS is associated with achievements in the areas of learning "culture and heritage" and "active citizenship". Çelikkaya \& Kürümlüoğlu (2019) also stated that in the fifth grade, CCPS related topics are included in the area of "culture and heritage" learning. This skill comes to the fore as it focuses on the change and continuity of cultural elements in the achievements of this learning area. In achievements, indicators of this ability to detect continuity and change over time, as well as finding similarities and differences, came to the fore. Celikkaya (2011) also showed that CCPS's indicators of finding similarities and differences with the perception of continuity and change that occur most over time in SSCEC were attainment to students.

In the sixth grade SSCEC, it was achieved that the attainments belonging to the learning areas "individual and society", "culture and heritage", "active citizenship" and "global connections" are related to CCPS. Achievements for this skill were not included in other learning areas. İneç (2020) stated that CCPS is at the center of this learning area. Çelikkaya (2011) also concluded that SSCEC partially attainmented CCPS. It has been observed that this skill is an indicator of the perception of continuity and change that occurs over time.

In the seventh grade SSCEC, CCPS was found to be associated with the achievements of all learning areas, except for the learning areas of "active citizenship" and "global connections". It has been found that skill is most associated with the achievements of the "production, distribution and consumption" learning area within these learning areas. In seventh grade SSCEC, CCPS "production, distribution and consumption" has been shown as a skill that is expected to be acquired by students in the area of learning (MoNE, 2018). Indicators of this ability to detect continuity and change that occur over time in achievements, as well as recognize past problems and causes, were included. It has been concluded that CCPS is most associated with seventh grade SSCEC among all grade levels. In addition, it was determined that the maximum number of learning areas that CCPS is associated with is seventh grade SSCEC. Özen \& Sağlam (2010) also concluded that seventh grade students were successful in explaining and using change and continuity.

It has been observed that TCPS is associated with all class levels and all areas of learning contained in SSCEC. However, it has been concluded that "culture and heritage" is heavily associated with the achievements of the learning area. Akbaba, Keçe \& Erdem (2012) also stated that TCPS should be acquired in this area of learning. In TCPS, the indicator for interpreting data in the maximum time lane is 
included. Altun \& Kaymakcı (2019) also stated that time lane has an important place in this skill. Mutluer (2013) stated that TCPS can attainment in Social Studies class in the opinion of teachers.

In the fourth grade SSCEC, TCPS was more intensely associated with the achievements of "science, technology and society" learning areas, as well as with the association of "culture and heritage" with the achievements of "people, places and environments" learning areas. This can be explained by the fact that the achievements of this learning area include the change and development of technological products from the past to the present. In contrast, in the SSCEC 4. grade, TCPS "culture and heritage" is shown as a skill that is expected to be acquired by students in the field of learning (MoNE, 2018). In the achievements, it was reached that this skill was considered to detect continuity and change that occurs over time, as well as indicators of finding similarities and differences.

In the fifth grade SSCEC, it was achieved that some achievements in the area of "culture and heritage" learning are associated with TCPS. It has been determined that these attainments are related to indicators of this ability to interpret data in the time strip and distinguish times. In this area of learning, where Anatolian and Mesopotamian civilizations take place, TCPS skills are needed to be able to recognize the contributions of these civilizations to human history and to better understand historical sites and cultural elements.

In the sixth grade SSCEC, TCPS was found to be associated with the achievements of learning areas "individual and society", "culture and heritage", "active citizenship" and "global connections". However, it has been concluded that this skill is more intensely associated with the achievements of the "culture and heritage" learning area. Işık (2014) also stated that in sixth grade SSCEC, skills related to time and chronology are included in the field of "culture and heritage" learning. In the sixth grade SSCEC, TCPS has also been shown as a skill aimed at attainmented students in the areas of learning "individual and society" and "culture and heritage" (MoNE, 2018). In contrast, Çelikkaya (2011) concluded that the program partially attainmented TCPS, in sixth grade SSCEC, this skill was considered with indicators of distinguishing times and interpreting data in the time strip.

In the seventh grade SSCEC, it was determined that TCPS is associated with the achievements of learning areas "culture and heritage", "people, places and environments", "science, technology and society" and "production, distribution and consumption". In the seventh grade SSCEC, TCPS has also been shown as a skill that is expected to be acquired by students in the areas of learning "science, technology and society" and "production, distribution and consumption" (MoNE, 2018). In the achievements, it was achieved that TCPS included indicators for distinguishing times, interpreting data in the time strip, and creating a time strip. In SSCEC, the highest attainment associated with TCPS was placed in the seventh grade of all grade levels. It has also been found that TCPS is most associated with "culture and heritage" learning area achievements. This can be explained by the fact that processcontaining content is very much involved in this area of learning. Çelikkaya \& Kürümlüoğlu (2019) also stated that in the seventh grade, TCPS related topics are included in the area of "culture and heritage" learning. Many studies have also 
mentioned that TCPS has an important place in Social Studies teaching (Şimşek, 2007; Işık, 2014; Altun \& Kaymakcı, 2016; Kekeç, 2018; Çelikkaya, 2019).

It has been determined that both CCPS and TCPS are associated with all areas of learning included in SSCEC. Both skills have been found to be most involved in the field of "culture and heritage" learning. In this case, it may be effective both to include history and culture issues in this learning area and to have a learning area (MoNE, 2018) where the duration rate (77.8\%) is highest in SSCEC. In addition, some attainments of certain learning areas have been found to be associated with these two skills. As a reason for this situation, it can be shown that the two skills are related to time and process.

In this study, which investigated the relationship of CCPS and TCPS with the attainments in SSCEC, it was concluded that both CCPS and TCPS were associated with the attainments of all class levels and all learning areas included in the program. In this direction, both of these skills are widely included in the program and how important these skills are from the point of view of SSCEC was revealed in the study. But it was determined that not all indicators of these skills were evenly distributed. It was concluded that some indicators were heavily involved in the attainments and some indicators were less involved.

\section{Suggestions}

In the study, it was concluded that both CCPS and TCPS are involved in SSCEC at all class levels and in all learning areas. However, although explanations of the content and indicators of these skills were included in the 2005 SSCEC, no explanations in this direction were included in the 2018 SSCEC. In order for teachers who are practitioners of the program to better understand these skills and better reflect them on the functioning of the course, SSCEC should include the content of these skills or even various explanations of how to acquire them for students.

In the 2018 SSCEC, explanations on learning areas are given in the section where attainments and explanations are given. In these descriptions, it is stated which skills will be acquired by students in the learning areas specified. According to these explanations, the learning areas that CCPS and TCPS will attainment to students are expressed. But according to the results of this study, it was found that both CCPS and TCPS are involved in more learning areas in SSCEC than are expressed in the program. For this reason, the areas of learning in which CCPS and TCPS are proposed to be acquired should be reviewed.

In the study, it was found that many attainments were associated with CCPS and TCPS. However, although the statement "values and skills are associated with achievements in the program" (MoNE, 2018) was included, there was explanation in the SSCEC as to which achievements CCPS and TCPS are associated, as with other skills. For this reason, explanations of what achievements these skills are associated with can be included in the program.

Some of the indicators of CCPS and TCPS were heavily involved in the attainments, while some indicators were not included in the attainments at all. For this reason, all indicators of skills can be distributed in a balanced way to achievements in order to fully attainment them to students. 
In the study, how much and at what level CCPS and TCPS were involved in SSCEC was investigated through document review. In different studies, the situations in which these skills are included in textbooks or acquired by students can be examined.

\section{References}

Akbaba, B., Keçe, M., \& Erdem, M. (2012). Effect of using multi-media to students' timechronology skills and perception skills of students' change-continuity. Afyon Kocatepe University Journal of Social Sciences, 14(2), 237-258.

Aksoy, B., Akbaba, B., \& Kılcan, B. (2019). Sosyal bilgilerde beceri eğitimi. Ankara: Pegem Akademi Yayınevi.

Altun, A., \& Kaymakcl, S. (2016). An education material on teaching time and chronology: Timelines. Turkish History Education Journal, 5(1), 157-192.

Avcl, E. K. \& Faiz, M. (2018). Investigation of the skills and values taking place in "effective citizenship" theme in 4th and 5th grade social studies text books. Uluslararasi Sosyal Bilgilerde Yeni Yaklaşımlar Dergisi, 2(1), 1-21.

Çiftçi, B., \& Akça, D. (2005). Comparison of geographical skills and geographical acquisition fields of 2005 and 2018 social studies curriculum. Eğitimde Yeni Yaklaşımlar Dergisi, 2(1), 33-59.

Çelik, H., Karadeniz, H., \& Cabul, E. (2018). Students' evaluations of change and continuity in the context of their experience in social studies classes: Hospitality example. Journal of Multidisciplinary Studies in Education, 2(2), 39-57.

Çelikkaya, T. (2011). Transmission level of skills in the social studies curriculum: Theacher's opinions. Kastamonu Eğitim Dergisi, 19(3), 969-990.

Çelikkaya, T., \& Kürümlüoğlu, M. (2019). A study on determination of chronology skills of secondary school students. Turkish History Education Journal, 8(1), 150-173.

Çoban, O. \& Akşit, İ. (2018). Comparison of 2005 and 2017 social studies curriculum in terms of learning area, acquisition, concept, value and skill. Journal of History Culture an Art Research, 7(1), 479-505.

Demircioğlu, İ. H. (2005). 8th grade students' levels of understanding of some concepts regarding time and chronology used in the teaching of history. Eurasian Journal of Educational Research (EJER), 19, 155-163.

Demircioğlu, İ. H. (2006). Zaman ve mekâna ilişkin becerilerin öğretimi. C. Öztürk (Ed.), Sosyal bilgiler öğretimi içinde (pp. 187-224). Ankara: PegemA Yayıncılık.

Gömleksiz, M. N. \& Cüro, E. (2011). An assessment of teacher's opinions on the meeting level of the social needs of the social studies curriculum (Sample of Diyarbakır city). Millî Eğitim, 190, 145-166.

Gürbüz, S. \& Şahin, F. (2018). Sosyal bilimlerde araștırma yöntemleri felsefe-yöntem-analiz. Ankara: Seçkin Yayıncılık.

Hayirsever, F. (2010). Evaluation of social studies textbooks, teachers' books and workbooks in terms of the basic skills to be instilled in students according to the social studies curriculum (Doctoral dissertation). Ankara Üniversitesi Eğitim Bilimleri Enstitüsü, Ankara. 
Pala, S. M. (2021). The place of change and continuity perception, time and chronology perception skills in...

Işık, H. (2014). Comparison of spatial cognition and chronology knowledge of the students of grade 6 in primary education and grade 9 in secondary education. Journal of International Social Research, 7(30), 111-121.

İneç, Z. F. (2020). Culture transfer in social studies teaching with virtual reality technology. Atatürk Üniversitesi Kazım Karabekir Eğitim Fakültesi Dergisi, (41), 180-203.

İncegül, S. (2010). An example in social sciences course oral history application (Master's thesis). Marmara Üniversitesi Eğitim Bilimleri Enstitüsü, İstanbul.

Kabapınar, Y., \& Sağlamgöncü, A. (2018). The efficiency of visual reading in terms of understanding "change and continuity" in social studies courses: An action research. İnönü Üniversitesi Eğitim Bilimleri Enstitüsü Dergisi, 5(9), 48-73.

Karasar, N. (2017). Bilimsel araştırma yöntemi: Kavramlar, ilkeler, teknikler. Ankara: Nobel Akademik Yayıncılık.

Kıncal, R. Y. (2017). Bilimsel araştırma yöntemleri. Ankara: Nobel Akademik Yayıncılık.

Kekeç, M. (2018). The use of modeling techniques in acquiring time and chronology skills (Master's thesis), Karadeniz Teknik Üniversitesi Eğitim Bilimleri Enstitüsü, Trabzon.

Ministry of National Education. (2018). Ortaöğretim coğrafya dersi (9, 10, 11 ve 12. sinıflar) ögretim programı. Ankara. Retrieved from: https://mufredat.meb.gov.tr/Dosyalar /2018120203724482-Cografya\%20dop\%20pdf.pdf

Ministry of National Education. (2005). Illköğretim Sosyal Bilgiler Dersi Öğretim Programı ve Kılavuzu (6-7. Sınıflar). Talim ve Terbiye Kurulu Başkanlığı, Ankara: Devlet Kitapları Müdürlüğü Basım Evi.

Ministry of National Education. (2018). Sosyal bilgiler dersi öğretim programı (ilkokul ve ortaokul 4, 5, 6 ve 7. siniflar). Ankara: MEB. Retrieved from: http://mufredat.meb.gov.tr/Dosyalar/201812103847686-

SOSYAL\%20B\%C4\%B0LG\%C4\%B0LER\%20\%C3\%96\%C4\%9ERET\%C4\%B0M\%20 PROGRAMI\%20.pdf.

Miles, M, B., \& Huberman, A. M. (1994). Qualitative data analysis: An expanded Sourcebook. (2nd ed). Thousand Oaks, CA: Sage.

Mutluer, C. (2013). The views of social studies teachers about the skills contained in social studies (The example of İzmir Menemen). Electronic Turkish Studies, 8(7), 355-362.

Özen, R., \& Sağlam, H. İ. (2010). Perception of primary studens on change and continuity. Akademik Bakıș Dergisi, 22, 1-15.

Safran, M., \& Şimşek, A. (2006). Development of historical time concept in elementary school's students. Illköğretim Online, 5(2), 87-109.

Sağlam, H., Tınmaz, E., \& Hayal, M. (2015). A phenomenological perspective on teaching experiences of perception skills of "time and chronology" of classroom teachers. Turkish History Education Journal, 4(1), 49-66.

Secim, O. (2019). Evaluation of change and continuity skills in geography course curriculum (Master's thesis). Marmara Üniversitesi Eğitim Bilimleri Enstitüsü, İstanbul.

Şimșek A. (2007). A quasi-experimental study to primary education 5th grade students' chronological perception's being improved. Kuram ve Uygulamada Eğitim Bilimleri, $7(5), 589-615$.

Patton, M.Q. (2002). Qualitative research and evaluation methods (3rd Ed.). London: Sage Publications, Inc. 
Patton, M. Q. (2014). Nitel araştırma ve değerlendirme yöntemleri. (M, Bütün \& S. B. Demir, Çev.), Ankara: Pegem Akademi.

Robson, C. (2017). Bilimsel araştırma yöntemleri; gerçek dünya araştırması. (R. Çınkır \& N. Demirkasımoğlu, Trans.). Ankara: Anı Yayıncılık.

Tangülü, Z., Tosun, A., \& Topkaya, Y (2015). Investigation of secondary school 7th grade students' social sciences lesson, change and continuity perception skill levels. The Journal of International Education Science, 2(4), 348-357.

Yıldırım, A. \& Şimşek, H. (2006). Sosyal bilimlerde nitel araştırma yöntemleri. Ankara: Seçkin Yayıncillk.

\section{Biographical Statement}

Şenol Mail PALA Erzincan Binali Yıldırım University, Refahiye Bahar Yıldırım Health Services Vocational School, Department of Child Care and Youth Services, Doctor in Child Development Program He serves as a faculty member. He studied Social Studies and Geographical Education. 